\title{
Kant's Practical Postulates and the Limits of the Critical System
}

\section{Sebastian Gardner}

The topic that I wish to consider is the significance, both systematic and historical, for Kant's system as a whole, of the postulates of pure practical reason, more specifically, of the two theological postulates concerning the existence of God and personal immortality which form the basis of Kant's moral theology. My discussion will focus on the problems of Kant's moral theology in the eyes of his early contemporaries, for whom it constituted a crux in Kant's project. Different views were taken by Kant's contemporaries of what exactly these problems signified regarding the future of Critical philosophy. For the thinkers I will be looking at here, the miscarriage of the moral theology constituted a fatal fault in the Kantian project. For the German Idealists, the moral theology instead provided a vital clue as to how the Kantian system could be transformed into a more radical idealism, while confirming that it needed to be. The role of the practical postulates in the development of German Idealism demands a separate treatment; what I will argue here is simply that the practical postulates do indeed represent a point at which Kant's philosophical system displays a deep and interesting tension, in light of which both historical responses are prima facie intelligible.

\section{Kant on practical cognition}

Let me begin with some examples of Kant's use, in connection with the moral theology and practical postulation, of the concept of practical cognition, praktische Erkenntnis. The following, key statements are taken from the second and third Critiques:

[T] he concept of freedom, insofar as its reality is proved by an apodictic law of practical reason, constitutes the keystone of the whole structure of a system of pure reason, even of speculative reason; and all other concepts (those of God and immortality) ... now attach themselves to this concept and with it and by means of it get stability and objective reality ... [A]mong all the ideas of speculative reason freedom is ... the only one the possibility of which we know a priori [...]. The ideas of God and immortality ... [are] only conditions of the necessary object of a will determined by this [moral] law, that is, of the mere practical use of our pure reason; hence with respect to those ideas we cannot affirm that we cognise and have insight into [erkennen 
und einzusehen] ... even the possibility of them. ... [T] heir possibility in this practical relation can and must be assumed ... . [B]y means of the concept of freedom objective reality is given to the ideas of God and immortality and a warrant, indeed a subjective necessity (a need of pure reason) is provided to assume them ... . [A]ll that is given is that their possibility, which was hitherto only a problem, here becomes an assertion. (CPrR, 5:3-5)

Here, too, the enigma of the critical philosophy is first explained: how one can deny objective reality to the supersensible use of the categories in speculation and yet grant them this reality with respect to the objects of pure practical reason ... . [T] he reality thought of here [gedachte Realität] does not aim at any theoretical determination of the categories and extension of cognition to the supersensible ... what is meant by it is only that in this respect an object belongs to them [ein Objekt zukomme], because they are either contained in the necessary determination of the will a priori or else are inseparably connected with the object of its determination ... . [P] ractical reason of itself, without any collusion with speculative reason, furnishes reality [Realität] to a supersensible object ... namely to freedom (although, as a practical concept, only for practical use). (CPrR, 5:5-6)

[The postulates of pure practical reason] postulate the possibility of an object itself (God and the immortality of the soul) from apodictic practical laws, but therefore only on behalf of a practical reason, so that this certainty of the postulated possibility is not at all theoretical, hence also not apodictic, i.e., it is not a necessity cognised with respect to the object but is, instead, an assumption necessary with respect to the subject's observance of its objective but practical laws of reason, hence merely a necessary hypothesis. I could find no better expression [than "postulate"] for this subjective but nevertheless rational necessity. (CPrR, 5:11n)

But is our cognition really extended in this way by pure practical reason, and is what was transcendent for speculative reason immanent in practical reason? Certainly, but only for practical purposes. For we thereby cognise neither the nature of our souls, nor the intelligible world, nor the supreme being as to what they are in themselves, but have merely unified the concepts of them in the practical concept of the highest good as the object of our will, and have done so altogether a priori through pure reason but only by means of the moral law and, moreover, only in reference to it, with respect to the object it commands. (CPrR, 5:133) 
Now they [the ideas of freedom, immortality and God] receive objective reality through an apodictic practical law, as necessary conditions of what it commands us to make an object, that is, we are instructed by it that they bave objects [da $\beta$ sie Objekte baben] ... . [T] heoretical cognition ... is extended by this insofar as objects were given to those ideas by the practical postulates [durch die praktischen Postulate jenen Ideen doch Objekte gegeben wurden], a merely problematic thought having by this means first received objective reality $[\ldots]$ insofar as the categories are to be applied to these ideas, it is not possible to give them any object in intuition; but that an object really exists [daß ein solches wirklich sei] ... is sufficiently assured them by an object that practical reason presents beyond doubt in the concept of the highest good. (CPrR, 5:135-136)

Our cognitive faculty as a whole has two domains, that of the concepts of nature and that of the concept of freedom [...]. There is ... an unlimited but also inaccessible field for our faculty of cognition as a whole, namely the field of the supersensible, in which we find no territory for ourselves, and thus cannot have on it a domain for theoretical cognition either for the concepts of the understanding or for those of reason, a field that we must certainly occupy with ideas for the sake of the theoretical as well as the practical use of reason, but for which, in relation to the laws from the concept of freedom, we can provide nothing but a practical reality [praktische Realität]. (CPJ, 5:174-175)

I can and indeed must conceive even of a supersensible being in analogy with an understanding, although without thereby wanting theoretical cognition of it, namely, if this determination of its causality concerns an effect in this world, which contains an aim that is morally necessary but unobtainable for sensible beings: for in this case a cognition of God and his existence (theology) is possible merely by means of properties and determinations of his causality thought in him by means of analogy, which in a practical relation, but also only in respect to this (as moral) has all the requisite reality [alle erforderliche Realität]. - An ethicotheology is thus quite possible. (CPJ, 5:484-485)

Kant's claim is that our postulation of transcendental freedom, the existence of God and our immortal souls, comprises rationally necessary practical cognition: the ideas of freedom, God and the soul receive 'objective reality', 'moral-practical reality', by means of the practical postulates. ${ }^{1}$ And yet, Kant also tells us, the necessity of assuming the postulates is not a necessity 'cognised with respect to the object' but with reference to the subject, a mere 'necessary hypothesis' by means of which we merely unify the concepts of 
God, freedom and immortality in the concept of the highest good as the object of our will: the extension of our cognition takes place 'only for practical purposes', the ideas having reality only from a practical point of view. In the 'Orientation' essay, practical cognition is described as not inferior in degree to theoretical cognition but as 'completely different in kind [der Art nach davon völlig unterschieden]' (OT, 8:141-142).

With these claims in view, the question which arises directly is whether practical cognition of the kind found in the theological postulates should be regarded as, to put it in the bluntest terms, a case of genuine knowledge. Does practical reason achieve cognition of the very same, really existing objects as theoretical reason seeks but is unable to cognise? Or does it instead make use of the idea of the supersensible in some way that is impossible for theoretical reason, a mode of employment that is not exhaustively and exclusively truth-directed?

It may be wondered if this is not somehow the wrong question to ask. Perhaps so it might be argued - our understanding of what it is for a judgement to be true or 'genuinely' cognitive, or to have an object, is refined in the Kantian context in a way that makes the question inappropriate. But Kant does not employ — not explicitly, at any rate - such a deflective strategy in explicating his concept of practical cognition, and on the face of it, so long as our ordinary grasp of the theoretical/practical distinction as concerning two opposed directions of fit with the world is allowed to remain intact, it is reasonable to confront Kant with the plain alternatives: either practical cognition by means of the postulates enjoys truth, reference and correspondence to an object in the same sense as is enjoyed by objectively valid empirical judgements and is aspired to by speculative claims about the supersensible; or it does not, and must instead merit the title of cognition on some other count, pertaining to the rational necessity of the manner in which it facilitates accordance of the will with principles of object-production, i.e. creates possibilities of action.

Various accounts of what it means to speak of practical cognition might, accordingly, be proposed. ${ }^{2}$ In the first instance, it may be suggested that practical cognition is simply cognition on a ground that is practical as opposed to theoretical, i.e. that 'practical' qualifies the reasons, evidence, or warrant, for a cognitive claim. Practical cognition would thereby designate a type of epistemic route to the object, or in a psychological idiom, the nature of the mode or faculty of cognition employed. Alternatively, practical cognition might be regarded as cognition of some content which belongs essentially to practical rather than theoretical reason, either in the sense that the nature of what is judged or represented is inherently practical, or in the sense that the judgement or representation is considered to have only practical significance, a role or function for (pure) practical reason. Or it may be proposed that practical cognition is just the analogue of cognition in the sphere of practical reason, the element in the practical sphere which most closely resembles it, entailing that cognition should either be put in inverted commas or understood to signify no more than a high degree of rational necessity. 


\section{Sebastian Gardner}

These accounts might be sifted and elaborated, but we do not need to go further in order to see that the important division is between what we may call realist interpretations, which take practical cognition to signify a relation between a representation and an object, and non-realist interpretations, which take it to signify either a relation between representations or a non-relational property of a representation. The meaning of Kant's principle of the primacy of practical reason, with which his concepts of practical cognition and practical postulation are closely bound up, changes for each interpretation: on a realist interpretation, the primacy of practical reason will be grounded on and reflect the cognitive superiority of practical reason, while on the nonrealist interpretations, it will reflect some other, pragmatic, non-cognitive superiority. The meaning of Kant's term of art, '(moral-)practical reality', will vary in a similar way.

There is, I think, no simple textual route to answering the question of whether or not Kant understands practical cognition realistically. Each of the interpretations accords in one way or other with some of the passages quoted, and can be argued to be contradicted by others. Furthermore, other places in Kant's texts where we might hope to find something that would settle the issue prove equally inconclusive. Thus if we look to Kant's official definition of a practical postulate, we merely get confirmation that practical cognition stands at the border, which it somehow crosses, of theoretical and practical reason. According to the definitions of a postulate and a practical cognition in Kant's Jäsche Logic, practical postulates are 'theoretical' because, unlike imperatives, they do not have 'an acting' but rather a 'being' as their object, and yet are 'practical' because, even though they are not themselves imperatives, they contain 'the grounds for possible imperatives' (JL, 9:86-87). ${ }^{3}$ If, instead, we look to what Kant says about the doxastic state involved in practical cognition, ${ }^{4}$ we find Kant asserting, in the classification of the different modalities of holding-to-be-true (Fürwabrhalten) in the Doctrine of Method in the first Critique, that moral judgements regarding how we should act are required to meet the standard of knowledge, Wissen, while judgements about the supersensible made on practical grounds are matters not of knowledge but of belief, Glauben. ${ }^{5}$ However, these distinctions of epistemic strength are not distinctions between judgements that should and should not be understood realistically: the concept of Kant's which does this which signifies that a concept or judgement has a relation to an object, objective reality is not Wissen but Erkennen, Erkenntnis. Kant uses the concept of Erkenntnis in the practical context only once in the first Critique, as far as I know, where it means simply knowledge of the moral law, of what ought to be. ${ }^{6}$ But in both the second and third Critiques, as we have seen, Kant affirms repeatedly that theoretical and practical reason comprise two spheres of cognition and that the latter achieves Erkenntnis of the supersensible. And yet, to repeat, these affirmations are invariably accompanied with the devaluative qualification that the cognition is merely practical - Erkenntnis is 'blo $\beta$ praktisch' - which does not seem to mean, or to mean only, a case of Glauben rather than Wissen, but rather appears to imply some inferiority in the nature or content of the cognition. 
At the risk of labouring the point, it may be added that even in the most seemingly forthright and committed of the passages quoted above - from CPrR, 5:135-136, located in the crucial Section VII of the Dialectic, where Kant's task is to explain how it is possible to extend pure reason for practical purposes without thereby extending speculative cognition - Kant shows signs of wishing to hold back from allowing the postulates to have objects in a full and unqualified sense. Reason, Kant writes, merely instructs itself (it is 'angewiesen') that its ideas have objects and this 'is not yet cognition of these objects [noch nicht Erkenntnis dieser Objekte]' (CPrR, 5:135). Elsewhere in the same section Kant tells us that when 'the objective reality' of the ideas is postulated they are 'declared assertorically [assertorisch ... erklärt werden] to be concepts to which real objects [wirkliche Objekte] belong', but that 'nothing further is accomplished in this by practical reason than that those concepts are real and really have their (possible) objects [jene Begriffe real sind, und wirklich ihre (mögliche) Objekte haben]' (CPrR, 5:134). In sum, Kant employs circumspect locutions which appear to mention rather than use the ascription of objective reality to the ideas. Kant's statement that objects are 'given' by means of the postulates, it may thus be argued, should be read as saying only that the practical point of view must represent its representations as having objective reality, not that there really exist objects conforming to the representations.

Kant's texts deserve more detailed scrutiny than space allows, but enough has been said to show that they leave us in some considerable perplexity. ${ }^{7}$ Yet the issue is not one that can easily be set aside, for much is at stake in the choice of interpretations, and neither is without its difficulties.

Consider the following account of the meaning of practical faith given by Fichte's colleague at Jena, Friedrich Karl Forberg:

Religion is nothing but a practical belief in a moral world-order [...] Religion ... is a duty [ist Pflicht]. It is a duty to believe in ... a God who governs the world according to moral laws. Yet this belief is by no means a duty in virtue of its being theoretical, that is, an idle speculation, but simply and solely in so far as it is practical, that is, in so far as it amounts to [ist] maxims of actual actions. In other words: it is not a duty to believe that there exists $[\mathrm{da} ß .$. existiert] a moral world-government or a God, it is simply and merely the duty to act as if one believed so [Pflicht, zu handeln, als ob man es glaubte]. (Forberg 1798: 21, 37-8)

By means of this quasi-reduction of the theological postulates to morality, what it is for one to believe the postulates to be true becomes just a matter - in itself specifiable without theoretical correlates - of directing one's will in a certain way. And though Forberg's account may strike one as barely a candidate for capturing what Kant had in mind, ${ }^{8}$ it follows textual leads left by Kant - the ubiquitous proviso, 'merely practical' and even matches a claim that Kant makes in one place, where he says that, when the 
ideas of God and immortality receive 'moral-practical reality', what this consists in is that we are to 'conduct ourselves as if [als ob]' their objects 'were given [gegeben wären]' (PT, 8:416).

The obvious objection to this approach is that it must, on the face of it, leave practical reason unsatisfied. The original motive for the theological postulates can hardly be fulfilled in Forberg's way, since, as Kant's arguments for the theological postulates as conditions of the highest good make plain, practical reason's need is for the objective reality of God and the soul, not just for a pragmatic ground for entertaining those representations - the final end of practical reason requires that there be a necessary concordance of Nature with Freedom, not merely that the subject represent a concordance. As one of Kant's early critics acutely puts it:

The presupposition of God's existence and of immortality is not the condition of fulfilment of the moral command, but rather the objective existence [objective Daseyn] of God and immortality themselves, as they really are, independent from our holding-to-be-true; and the mere presupposition of immortality cannot give reality to the object of the command to achieve holiness of will. (Schulze 1792: 435)

Forberg's non-realist interpretation would appear to make nonsense of Kant's claim, in his 'Orientation' essay, to be able to provide by means of rational faith everything that a theist such as Jacobi can reasonably demand.

Plausibly, the only way for a non-realist view of practical cognition like Forberg's to stand as an account of Kant's theological postulates would be on the basis of a generally pragmatic or otherwise anti-realist construal of Kant's philosophy, according to which all necessity is regulative and none constitutive. The postulates could not then be regarded as cognitively inferior to any other rational claim or as in any respect more problematic. ${ }^{9}$ It is no accident that Forberg's essay is part-reproduced in the back of Hans Vaihinger's book, Die Philosophie des Als $O b$, in which Vaihinger hails the as-if conception of Kant's postulates as displaying the 'true Kant', 'the highest point' in Kantian philosophy (Vaihinger [1911] 1949: 327). Any such account must, however, be classed as reconstructive rather than exegetical. That Kant himself would regard bare 'as if claims as inadequate to the task of the moral theology is implied by his denial that the mere hope of achieving the highest good is sufficient for moral purposes: the theological postulates are intended by Kant to ground hope, not merely to express it. ${ }^{10}$

But the realist interpretation too has its obvious problems, or at least, it raises some very big questions. If by means of the postulates objects are given to us as existing, then even if we remain ignorant of how these objects are 'in themselves' - even if our cognition is unavoidably analogical in character ${ }^{11}$ - still we have a clear case of the supersession of theoretical reason by practical reason, and must credit ourselves with a cognitive competence which, if not strictly equivalent to a power of intellectual intuition, 
does the same job. And while this would make good sense of Kant's claim to have established a 'practical-dogmatic metaphysics', 12 it would leave us wondering whether Kant should not simply come clean and acknowledge that what he calls 'practical cognition' of the supersensible is in fact a higher form of theoretical cognition cognition of theoretical reason based not on sensible intuition but on purely intellectual data furnished by our practical faculty. ${ }^{13}$

\section{The relation of morality and happiness in Kant's moral theology}

With this outline of the basic issue completed, I now want to look at the criticisms of the moral theology by Kant's contemporaries, and its relation to the Critical system as a whole. The chief criticisms found in the earliest literature can be divided into three sets. Each in turn exposes deeper roots of the moral theology in Kant's system as well as a higher degree of involvement of moral theology with questions surrounding Kant's philosophy as a whole.

The first set bears on Kant's introduction of the concept of happiness in the Dialectic of Pure Practical Reason and his related construction of the concept of the highest good. The central line of objection is that the concept of happiness, being part empirical, has no rightful place in the system of pure practical reason, and that the role which it is required to play in Kant's argument for moral theology directly contradicts certain fundamental principles of his moral theory, namely the supreme authority of the moral law, and the absolute independence of moral motivation from inclination. ${ }^{14}$

This objection - which has deeper ramifications in so far as it provides a medium for targeting more broadly the freedom/nature and intelligible/sensible dualisms of Kant's moral theory and, thereby, of his transcendental philosophy as a whole - drew particular encouragement from the infelicitous cast of Kant's original presentation of his argument for the moral theology in the first Critique, where Kant allowed it to seem as if religion is required to set incentives (in the form of divine rewards and punishments) to moral action. ${ }^{15}$ Kant's subsequent restatements of the moral theology incorporate successive refinements and shifts of emphasis, ${ }^{16}$ and it is fair to say that the best comprehensive statement of Kant's argument for the necessity of supplementing the moral law with the highest good results from conjoining elements from several different presentations of the argument, including those of the second and third Critiques and the short remarks in the Religion book. Thus properly articulated, and set within the context of his moral theory, Kant's argument seems to have considerable force and does not succumb to charges of inconsistency. Though a full defence of this claim would require a lengthy discussion, the following points may give a quick indication of why this is a reasonable assessment.

First, Kant's claim is not that the highest good is deduced from the concept of the moral law, ${ }^{17}$ but that it emerges from the self-reflection of a finite being with a capacity for obedience to the moral law and subject to inclination. The highest good has its source 
not in pure reason as such, but in the situation of a being who must strive to conform to pure practical reason: it results from the self-reflection of practical reason as a whole, a whole which is governed by, though necessarily not identical with, pure practical reason. Second, it is not the sheer force of inclination - of desire qua desire - that explains the inclusion of happiness in the highest good, but the judgement of practical reason that happiness has a legitimate (albeit merely prima facie, morally conditional) rational claim. There is, on Kant's account, a rational purposiveness to the imperative to achieve happiness, which is why its sacrifice represents a cost that there can be a rational interest in recouping. Third, the highest good is not itself a practical norm and so cannot compete with the moral law, ${ }^{18}$ nor is it strictly speaking, although it is an end, an object of my will: it is an object of hope; my hope being that the end of achieving the highest good will come to be realised through the attainment of the object of my will - which remains simply the fulfilment of the moral law. The highest good is therefore not even a conditional incentive: rather it is what eliminates the disincentive to morality which comes from reflection on the respect in which the moral law is counter-purposive for subjects of inclination. ${ }^{19}$

In sum, the alleged paradox in Kant's claim for the practical necessity of the theological postulates as conditions for the highest good disappears when it is seen that Kant can legitimately distinguish (i) the grounds for grasping the moral law as having rational authority and thus as motivating, from (ii) the conditions necessary for setting oneself the comprehensive reflexive aim of acting as a human being determined by the moral law; a distinction which is rationalised by the dual, rational-sensible character of human agents. Fulfilment of (ii) becomes imperative when rational agents factor in to their practical reflection their identity as subjects of inclination. This provides a sufficient basis for explaining how it can be true that the non-realisability of the highest good would nullify the moral law, without its being true that self-love belongs in any way to the grounds of its rational authority. ${ }^{20}$

\section{The relation of practical and theoretical reason in Kant's moral theology}

The second set of objections to Kant's theological postulates bears on the relation of the two faculties of reason implied by the notion of cognition from the practical point of view. According to Kant, the ground of the theological postulates lies in moral need. The difficulty alleged by Kant's critics concerns Kant's reasoning from a practical need to the objective reality of ideas of reason. The following objection was put many times by Kant's contemporaries: In general, as a principle of sound common understanding, a need or interest can be allowed to play a determining role only if the need is well-founded and if its mode of determining fulfils the relevant rational conditions. Suppose Kant succeeds in showing the necessity, for a moral agent, of willing the highest good, and the necessity of the postulates for willing the highest good. Still, what is held to be determined by this well-founded need is a belief. Hence it must be shown that it is possible for me to form 
the belief in question. This I can do, however, in view of the intrinsic nature of belief, only if there are reasons for holding it true. So morality can ground the theological postulates only if they are already theoretically grounded, or capable of being theoretically grounded, contrary to what Kant claims, and in any case making their practical justification redundant.

The complaint that Kant's moral theology interpolates a normative relation in the absence of any rational connection, and in violation of doxastic norms, is voiced by critics of diverse persuasions, including Jacobi's ally Thomas Wizenmann, Johann Friedrich Flatt of the Älteren Tübinger Schule of biblical rationalism, the empiricist Popularphilosoph Johann Georg Feder, and the sceptic Gottlob Ernst Schulze. ${ }^{21}$ Wizenmann suggests that if it is rational for a thinking being to presuppose and believe in a God for whose existence all grounds are missing, merely because the belief is needed for the practical use of his reason, then by parity of reasoning it must be rational for a lover to believe that he is loved by a creature which he has no grounds for supposing to be real, merely because he stands in need of that belief. ${ }^{22}$ The objection is put in general terms by Feder:

The wish, however strong and noble it may be, that something be the case, is on its own no ground for the assertion that it is the case. The virtuous man can certainly say: I will, that there be a God. But when he reflects, he sees directly that nothing is established by this willing ... . [T]o believe, to hold true, merely because it accords with wish and will - not even the most virtuous man can on reflection do that, and at the same time heed his reason. Judgements and convictions of the understanding do not depend on the will; they have their own laws. (Feder 1790: 47)

It is entirely possible, Feder grants, that a morally good man should find himself in the condition described by Kant — of being, through force of interest, simply unable to relinquish some belief - but this cannot count as an argument of any sort and should not be presented as such. ${ }^{23}$

Kant's difficulty is described in Flatt's Briefe (1789). Flatt claims that to argue in Kant's fashion, on the basis that hope of achieving the highest good is needed to prevent all motives for following the moral law from falling away, is to endorse a principle which blatantly contradicts a law of common understanding, viz. that it is impossible to hold a principle true, merely because it contains no contradiction and because holding it true is fitting or necessary for some practical goal. That the practical interest may be strictly universal changes nothing; what matters is that it is independent of all theoretical grounds of cognition. ${ }^{24}$ Flatt agrees that I must (rationally) wish that the proposition be true, and that grounds be found for holding it true, but this wish, however strong and rational it may be, cannot take the place of a ground of truth, a Wabrheitsgrund; the most it can do is 


\section{Sebastian Gardner}

induce me to seek such a ground (which Flatt thinks can be found, in the old speculative proofs of God).

A slightly different statement of the objection - locating Kant's infringement of norms at a different point — is given by Schulze in the Fifth Letter of his Aenesidemus (Schulze 1792: 415-445). Schulze asserts that it is universally true - and the present case can be no exception - that imperatives are valid for an agent only when the agent is able to carry them out: before any candidate imperative can be accepted and acted on, it must be determined that the conditions which are necessary for its fulfilment do in fact obtain. The possibility of carrying out a command is a condition for our assent to it. A man cannot be commanded to fly like a bird. Similarly, regarding the laws from which commands derive: a law that demands an impossible action is no law for us. ${ }^{25}$ In all cases, determining that the conditions of possibility for imperatives obtain is a task for theoretical reason to perform, prior to our assenting to the imperative. The means for performing this task are themselves circumscribed independently of practical reason, for we cannot be commanded to regard something, whatever it may be, as an Erkenntnisgrund (Schulze 1792: 435). It might be thought, Schulze notes, that Kant's moral proof requires only that we reason in a purely instrumental practical manner, applying nothing but the simple rule that one should will the necessary means to one's ends, in the following way: The highest good is my final end, to which presupposing God and my immortality are means; therefore, let me presuppose God and my immortality. Schulze grants that the means-end rule creates no problem for the derivation of the postulates; what creates the problem is another, no less binding rule, namely that what one undertakes to do should be something that one can do. Theoretical reason must, it follows, have priority over practical reason in the respect isolated: we must have theoretical knowledge of God and immortality before we can take up the task of willing the highest good. Schulze concludes that Kant's moral theology is abortive.

The formation of a consensus concerning the failure of the moral theology on the count just described is evidenced by Johann Friedrich Breyer. Breyer holds a special interest, in so far as he was one of the very first to declare himself a Kantian and authored in 1785 a work entitled The Victory of Practical over Speculative Reason (Sieg der praktischen Vernunft über die spekulative), in which he hails Kant on the grounds which, a year later, motivated Reinhold to publicly champion Kant's cause. By 1789, however, Breyer's estimate was flatly reversed. He now sees no difference between Kantian Vernunftglaube and Jacobi's Glaube, speaking of the 'salto mortale im System des Königsbergischen Philosophen' on which Kant's whole moral theology reposes. Kant jumps 'over whole cliffs and clefts in so far as he makes rational belief in God depend on nothing but the mere will of the virtuous':

[It is] absolutely impossible to hold true any proposition, even if it contains no contradiction, for the reason and solely for the reason that the holdingtrue of it conduces to or is necessary for the achievement of some practical 
final end. Of such a proposition I must indeed continue to wish that it be true ..., but the wish itself, however strong and however reasonable it may be, can never take the place for me of a ground of truth ... . Belief in God and an afterlife, if it is to be a rational belief of mine, must be supported on grounds other than mere interest. ${ }^{26}$

We should now consider whether it is true that Kant's moral theology misconceives the relation of theoretical and practical reason in the way these critics suppose.

Kant has an effective response to at least part of the objection. Replying to Wizenmann in the second Critique (CPrR, 5:143n), Kant insists on the difference between the case of morality, and cases where a belief is formed on the basis of some empirical need or interest, such as, to take an example from Feder, where one is uncertain whether the water is drinkable and consequently decides to believe that it is poisoned, in order to make drinking it easier to resist (Feder 1790: 45-46). What is wrong with taking one's empirical needs and wishes as grounds for belief is simply that we know the two states of affairs - of wanting $p$, and of its being the case that $p$ - to be independent. In the context of pure practical reason, however, this piece of worldly high-level empirical knowledge is irrelevant, and to suppose otherwise is to confuse pure with empirical practical reason: we do not know the relation of the needs of pure reason to their objects to be merely contingent, for it may be that necessarily what pure reason needs is the case. Nor is Kant obliged to accept Schulze's charge of absurdity in his construal of the conditions for rational imperatives: in a sphere where theoretical judgement is in Kant's sense wholly problematic, the conditions governing the validity of merely empirical imperatives need not be upheld. The principle to which Kant's moral argument appeals is, in short, a rule of inference with one instance of application only, viz. of inference from moral interest, ${ }^{27}$ and it does not authorise empirical inferences from wishes or hopes that $p$ to beliefs that $p$.

Kant cannot, therefore, be charged with employing a principle of inference which ordinary understanding regards as invalid. But even if there is no direct route to impugning Kant's reasoning as supposed by Wizenmann, Flatt, Feder, and Schulze, still it does not follow that Kant's reasoning is sound: granted that the purity of moral practical reason creates a relevant asymmetry with empirical practical reason, the cause of the theological postulates still needs to be pleaded.

Kant's repeatedly stated position is that the crucial work is done by the disclosure of transcendental freedom in the fact of reason, which securely transfers us to the supersensible realm.

The first thing to note, however, is that the transmission of warrant from freedom to the theological postulates cannot be direct, for even if the latter are allowed in principle to share in the practical necessity of the freedom postulate, their validation cannot similarly take a practical form. Nor does Kant pretend that it can: the theological postulates are differentiated, as mediate cognitions, from the freedom postulate, which 


\section{Sebastian Gardner}

alone comprises immediate cognition of the supersensible (CPrR, 5:3-4). ${ }^{28}$ The cognition of transcendental freedom is grounded directly on my pre-philosophical grasp of my capacity to conform my will to the moral law implied by my respect for that law. The content of my belief that I am free thus remains immanent in the sense that, although a supersensible state of affairs is in question, the perspective of practical reason allows me to refer the representation of transcendental freedom immediately to the sphere of endeavour. Through setting my will I take up the idea and validate the assumption of transcendental freedom; the theoretical question of whether I am transcendentally free is referred directly to what it is within my own power to determine through moral exemplification.

Nothing analogous is available for the propositions that God exists or that my soul is immortal: there can be no practical reflexive pressure to assent to the theological postulates in the way that there is for the postulate of freedom, since the question of whether God exists is not one that, in the very entertaining of it, allows and directs me to answer it through the determination of my will. So although practical reason can require theoretical reason to accept the theological postulates, as it does the freedom postulate, practical reason cannot assist theoretical reason in doing so in the way that it can with regard to the freedom postulate.

The next point to recall — which we have just been reminded of - is that the theological postulates are not imperatives but propositions with assertoric form, and so must be believed to be true, which brings them within theoretical reason's sphere of jurisdiction.

Kant says several things designed to lighten the load of theoretical reason. In the first place Kant is clear that the formation of the belief is the work of practical, not theoretical reason: the judgement appears spontaneously in the consciousness of the morally good person. ${ }^{29}$ In consequence, the doxastic state is indexed to the subject in a distinctive way: 'I must not even say "It is morally certain that there is a God", etc., but rather "I am morally certain" etc.' (A828-9/B756-7). ${ }^{30}$ Third, theoretical reason does not stand under a duty: it does not have to think of itself, self-destructively, as an organ of practical reason (CPrR, 5:125). Fourth, Kant half-suggests that the true subject of belief, what does the believing, is not theoretical but practical reason. ${ }^{31}$ Finally, Kant emphasises that theoretical reason is not required to grasp how practical cognition is achieved - 'we are not able to show how their concept refers to an object [wie sich ihr Begriff auf ein Objekt bezieht]' (CPrR, 5:135) — and that in any case it does not allow us to know the objects 'as to what they are in themselves [was sie an sich selbst sind]' (CPrR, 5:133) but merely expresses 'the relation ... to an object of our practical reason' (CPJ, 5:457).

Be all that as it may, practical reason is not insulated from theoretical reason, and theoretical reason cannot be envisaged as turning a blind eye to it: theoretical reason must register practical reason's belief and take a view of what it is doing, that is, form an estimate of the belief formed. Kant of course acknowledges this, otherwise there would be 
no need to invoke a principle of the primacy of practical reason. So what view can theoretical reason take of practical reason's theological postulates?

In so far as theoretical reason regards the argument for the postulates as reasoning which is practical in nature, it will grasp a piece of strategy in which the representations of God and the soul's immortality facilitate the representation of oneself as bound by the moral law. But if theoretical reason stops at this point, then it is merely left with knowledge of the beliefs of practical reason, as one person has knowledge of the beliefs of another, and while it can affirm that practical reason has successfully completed a strategic operation and in that sense can 'approve' its operation as means-end rational, it has come no closer to being able to assent to the judgements that issue from practical reason, since these are judgements not about representations but about their putative objects.

Since theoretical reason cannot regard the argument for the theological postulates as simply and exclusively practical in nature, it must instead take up and rehearse for itself practical reason's moral argument for the theological postulates. In so doing it will be concerned not with representations alone and the relations between them, but with representations in relation to their putative objects; in other words, it must determine whether or not the representations have objects. Since, in making this attempt, theoretical reason cannot be determined by the practical necessity of doing what the moral law demands, the closest that it can come up with, plausibly, is a piece of reasoning which will look something like this: The validity of the moral law is an objective fact, and its existence is something which requires explanation; we are entitled to affirm the reality of whatever is a condition for the existence of given things; God's existence is a condition for the existence of the moral law; so God's existence is to be inferred from the existence of morality. ${ }^{32}$ The problem is that even if this argument were formally valid, it is of course exactly the kind of non-transcendental, dogmatic Wolffian argument that Kant attacks in the Transcendental Dialectic and that Critically enlightened theoretical reason cannot accept. ${ }^{33}$

If theoretical reason cannot recoup for itself the moral argument for the theological postulates, then reason as a whole is left with a kind of double vision. On the one hand it grasps the strategic inter-relation of representations, an awareness which is self-directed (it has a point of view on the postulates); on the other, it takes itself to have awareness of the objects of those representations (it occupies the point of view of the postulates); and the two are not harmonised, because awareness of the relation between representations does not give grounds for the alleged awareness of a relation to an object.

It is consequently tempting to speak of a doubling of perspectives, or even of there being two arguments for the theological postulates in play, superimposed upon one another. There is, first, a ground which operates spontaneously from inside the perspective of belief in the postulates, which we are to think of as consisting in a direct insight into a connection between 'the moral law's being valid' and 'God's existing', an insight which makes reference to the moral law and to God, but not to my 
representations thereof - it uses the representations of God and the moral law without mentioning them. Then, second, there is the explicitly stated argument for the postulates advanced by Kant, which consists in reflection on what it would mean for me if I lacked belief in God and immortality, and which does refer to and is in some way about my representations. What Kant offers as a basis for religious faith appears to be ambiguous between the two: the first corresponds to what supposedly takes place in prephilosophical natural consciousness, and recalls the philosophical innocence of Rousseau (or the sophisticated naivety of Jacobi), while the second constitutes a relatively abstruse line of reasoning available only to the philosophically adept. ${ }^{34}$ The problem with the doubling is not the multiplication of grounds as such - an argument at the level of objects can parallel and complement an argument at the level of representations - but the fact that the second argument threatens to undercut the first: to explain away the pretension to rational insight in terms of the mere intra-subjective functional roles of representations. 35

If we drop the talk of multiple faculties and return to the subject as a whole, as the unity of reason doctrine requires that we do eventually, it becomes clear that I must have some conception of the significance of the fact that I hold beliefs on grounds supplied by practical reason, even if the beliefs are ones that I already find myself with rather than set myself to form. Since I cannot believe qua practical and not believe qua theoretical, a unified conception of my state of mind is required. What creates the pressure here is not the unity of the 'I' - the transcendental unity of apperception is a unity of the understanding — but the combination of Kant's theses of the unity and the autonomy of reason: if reason is unified, then a single estimate of the theological postulates must be shared by each of its forms, and if reason is autonomous, then it must be autonomous in each of its forms. The autonomy of reason as a whole can transmit itself unproblematically to each of its species if each species of reason has a discrete domain, but in the present context that is not the case: the theological postulates respond to a need of practical reason while requiring the sanction of theoretical reason.

The problem, ultimately, is that even when the formidable case made by Kant for the comprehensive rationality of the theological postulates - his account of their practical necessity, agreement with reason's systematic interest, coherence with the regulative principles of theoretical reason, etc. — is granted, the subject's understanding of why he accepts them must fall short of giving him grounds for thinking that what he believes is true. Thus even without there being a strict contradiction of theoretical and practical reason, there is still an alienation within reason of a kind which would raise a shrug in Hume but must discomfit Kantians, who are obliged to admit that, in regard to the theological postulates, reason is in one respect opaque to itself. In this sense and to this degree, I suggest, the objection of Wizenmann and the others has force.

If we now return to the choice of realist and non-realist interpretations of practical cognition, we can see that, in order to rebut conclusively the objection that he has construed the practical/theoretical relation if not incoherently then at least in a fashion 
that makes reason puzzling to itself, Kant would need to choose once and for all between them. A clear and unqualified acceptance of either the realist or the non-realist interpretation will re-harmonise theoretical and practical reason. For if theoretical reason can either accept practical reason as an original, rational source of cognition, or alternatively, if it can regard the religious postulates as making no claim to cognition at all, and practical belief in them as not a case of genuine holding-true, then the problem identified by Wizenmann et al. vanishes.

\section{Practical Postulation and Kant's Copernicanism}

We come now to the third class of objections. Here connections are drawn between problems encountered by the moral theology and the project of Critical philosophy as such.

It should be recalled that, in contrast with our present tendency to view the moral theology as something of a detachable addendum to Kant's system, until fairly late in the 1790's the Kantian philosophy was regarded, in the manner that Reinhold had recommended in his Letters, as a programme the entire rationale of which lay in resolving the outstanding Aufklärung problem of reconciling reason with religion, such that the failure of the moral theology would directly entail Kant's philosophical failure. ${ }^{36}$ The particular attacks on Kant by way of the moral theology which are of interest to us at the present point are those in which Kant's critics claim to have arrived at a deep diagnosis of the problem afflicting Kant's moral theology: the real fault, it was alleged, lies in Kant's Copernicanism, his transcendental method, the employment of which in the theological context merely displays the deeper, insuperable problem confronting the Critical philosopher.

The problem was identified in various ways. Feder alleges that belief in God is impossible within the Kantian system - even if its inference from practical need were not invalid - because of its 'essential supreme principle', that we do not have knowledge of things in themselves (1790: 65-66), entailing, Feder insists, that the very concept of God must be for us 'without meaning'. The moral theology thus controverts Kant's principle of ignorance of things in themselves, directing us back to (empiricist) transcendental realism. On the opposite wing, Flatt endorses Kant's moral ground as sufficient for religion, but only on the condition that one detaches it from the Copernicanism of the Kantian system: the validity of Kant's argument for his moral theology forces him to concede the principle that 'that which reason is necessitated to think as external to the mind, really is present outside our representation', 'the foundational presupposition, that the objects outside our representation agree with the necessary determinations of our reason' (Flatt 1789: 102-103). And as Flatt notes, once this presupposition is granted, it may be employed to lead us to the idea of an intelligent author of nature. In other words, if Kant's moral theology succeeds, then dogmatic rationalism is back in business. 


\section{Sebastian Gardner}

Schulze makes essentially the same criticism as Flatt, but to sceptical effect. On the basis of his construal of the moral proof as seeking to infer from some thing given to us the reality of the conditions under which alone that thing is thinkable for us (Schulze 1792: 436-437), Schulze claims that the moral theology requires that we make an inference from what we must think or presuppose, mere 'subjektiven Gedachtwerdenmüssen', to what there must really be, 'objektiven Seyn': in order to fulfil the requirements of the moral law, I must presuppose God and immortality, therefore God and immortality must really exist (Schulze 1792: 433-434). ${ }^{37}$ The inference is of a type which is both invalid by the lights of Critical philosophy and vulnerable to sceptical objections to which Critical philosophy has no answer. Since Kant's moral theology leaves scepticism unrefuted, it makes no cognitive advance.

Wizenmann, noting that Kant describes the grounds of practical faith as subjective yet rational, argues that it is impossible to sunder subjective principles of reason from objective ones in such a way that a purely subjective principle can function rationally as a determining ground of holding something true: subjective principles of reason, he says, can concern only the form of our own existence, so that it is in the very concept of such principles that they can provide no basis for either affirmative or negative judgement of objects. When, therefore, in the case of the practical use of reason, Kant declares that reason needs God for the sake of morality, this reasoning must be regarded as at the same time objective, just like the 'dogmatic' proofs that Kant rejects. But to take subjective grounds as objectively indicative is to allow one's belief to be determined by grounds that, one knows, attest to nothing with regard to the matter at issue - which is tantamount to Schwärmerei. ${ }^{38}$ There is moreover, Wizenmann alleges, a puzzle surrounding the very idea that reason 'needs' the extra-representational existence of anything whatever, whether of God in the practical context or of the unconditioned in the theoretical, as opposed to needing merely the fulfilment of epistemic desiderata such as certitude and systematic order within the sphere of its representations (Wizenmann 1787: 139). Kant's commitment to the principle that the mere presuppositions of subjective reason contain and bestow objective reality, Wizenmann implies, effectively absolutises reason, an inflation of the faculty that is itself irrational (Wizenmann 1787: 139-140).

Perhaps the most forceful statement of the objection comes from Jacobi, who in Ueber das Unternebmen des Kriticismus (Jacobi 1801: 175-195) reapplies to Kant's postulates the same type of criticism that he had earlier applied to Kant's claim of empirical realism in 'On Transcendental Idealism', the Supplement to his David Hume on Faith (1787). According to Jacobi, the difference between the two cases, which are otherwise parallel, concerns merely which faculties are involved, with reason, in the case of the practical postulates, occupying the place of the understanding in that of empirical knowledge. Jacobi's central objection is that Kant's own account of the subjective genesis of the ideas of reason not merely fails to positively endow them with any epistemic authority, but makes it impossible to regard them as having any cognitive significance whatever: it is impossible to conscientiously have an 'honest, wholehearted confidence' in reason's ideas 
of God, freedom and immortality, since we are on Kant's account 'clearly instructed by the origin, the constitution and the inner essence of these ideas' that they are only 'Fictionen' - they arise in us only because they are necessitated to do so by the conceptual operations of the understanding, as required in order to provide bounds for its extension, and so can only be taken as deceptive horizons, not as things existing for and in themselves (Jacobi 1801: 100-103). ${ }^{39}$ Since the final justification and end of the whole Critical undertaking, Kant himself has told us, was precisely to save the three practically significant ideas of reason, we can conclude from his failure in that broader endeavour, according to Jacobi, that the Critical project runs aground. ${ }^{40}$

The practice of evaluating the Critique of Pure Reason and Kant's moral theology as a unified package, in which the moral theology represents the culmination, experimentum crucis and, according to his critics, reductio ad absurdum of the Critical undertaking, is exemplified in numerous places in early Kant reception. ${ }^{41}$

The criticisms I have cited follow different patterns and obviously raise many issues, concerning Kant's theory of reason and other matters, but the core of the objection, I suggest, can be formulated as follows.

It is natural to read Kant, as the critics I have referred to clearly do, as aiming in the moral theology at a transcendental realist conclusion - at a cognition, however emphatically qualified as 'merely practical', of things in themselves. This coheres with Kant's avowed strategy of limiting reason to one sphere - the theoretical, where cognition is confined to appearances - in order to permit its expansion in another the practical, where cognition extends to intelligible entities, a division of competences by means of which the strength of cognitive claims is apportioned to their importance for us: our highest vocation lies in practical reason, whereas the ends of theoretical reason have only conditional value, Critical philosophy thereby reserving 'real' cognition for the context where it really matters.

This construal of Kant directly invites the criticism we saw above. Even without leaning on Feder's view of Kant's philosophy as committed to denying us all knowledge of things in themselves - or Jacobi's equally tendentious claim that the ideas of Kantian reason are inherently fictive ${ }^{42}$ — there does nonetheless appear to be an inconsistency between the strength of the cognitive claim which Kant intends in his moral theology and the weakness of cognitive warrant possible under the conditions of Kant's epistemology, and plausibly the gap cannot be held to be overcome by retreating to the practical point of view. For, quite aside from the reasons explored in the previous section, which concerned the problem of lateral transmission of practical cognition to the theoretical faculty, there is the more fundamental problem that the means employed to erect cognition of God from the practical point of view are essentially no different from those employed in Kant's theory of empirical reality. In both cases, what is required to do all of the work in securing objective reality for our representations is the autonomous, selfdirected operations of the subject: the requirement of the unity of apperception forces the production of empirical objects; that of moral will, the production of the highest 
good and the theological objects which are its conditions. It is, therefore, as if Kant had attempted to use a form of philosophical justification designed specifically for appearances - for establishing conclusions about things which are to be taken to exist merely as subject to, and as functions of, necessities of representation - in order to reach a result concerning things as transcendent of representation. This explains why it should appear to Jacobi et al. as if Kant has attempted to argue by Copernican means, i.e. on the basis of a consideration of what representations are necessary for us, to a transCopernican result, a conclusion which goes beyond the necessities of representation; whereas in fact necessities of representation are all that the Copernican method is capable of establishing.

This allows us to see that, although the second objection to the moral theology paves the way for the third - by drawing attention to the gap which theoretical reason finds between practically necessitated representations and their supposed objects ultimately the third objection overtakes the second. Even if the needs of reason were not, as they are in the moral-theological context, 'merely' practical in nature, they continue to remain just formal structures in the self-relation of a subjective faculty.

One correction to the argument as just stated is needed. The construal of Kant on which the criticism rests fails to take account of Kant's unequivocal statements that the objects of practical cognition are cognised not as they are in themselves but only qua 'predicates drawn from our own nature', predicates of 'understanding and will, considered moreover in the relation to each other in which they must be thought in the moral law' (CPrR, 5:137). ${ }^{43}$ But although this changes the situation in one regard, it does not remove the problem facing Kant. If the objects of practical cognition incorporate subjective conditioning, deriving from the structure and function of our finite practical reason, then they are in some sense transcendentally ideal. While this point might seem initially to Kant's advantage, allowing him to reject the suggestion that his moral theology attempts but fails to arrive at transcendental reality, it still leaves him with a very difficult question to answer. In the case of empirical objects, Kant is able to give an account, through the theory of synthesis, of how subjective conditions are carried over into and constitute the object which conforms to them. In the case of the freedom postulate, again, Kant has a story to tell about what it is for a subjective element, an idea, to constitute an object (a determination of the will). But no similar account can in principle be provided for objects which, though in one weak sense 'belonging to' practical reason, in another and very clear sense are as transcendent for it as they are for theoretical reason. Nor - in view of the Copernican exclusion of hypotheses concerning the providential intentions of God in endowing us with reason - does any other explanation of the agreement of subjective representational features with putative objects seem possible. The objects of the theological postulates are thus anomalies in Kant's ontology; their status as so to speak 'noumenal appearances' - analogues in the intelligible realm of empirically real appearances — is not elucidated by Kant. 
Kant's critics characteristically supposed that the incontrovertible failure, as they saw it, of the moral theology undermines Kant's theory of empirical knowledge, by exhibiting the global inadequacy of Copernican foundations for cognitive claims in general. This, however, should be regarded as doubtful. While it may be true that the moral theology's collapse into subjectivism throws into sharp relief the transcendental subjectivity of Kantian appearances, it is a properly separate matter, requiring further argument, whether this actually constitutes an objection to Kant's account of empirical knowledge. On the face of it, it appears quite possible to separate the two cases and to maintain the viability of Kant's account of empirical reality while conceding the untenability of the moral theology, simply on the basis indicated above, that there is at least one context where Copernicanism is properly at home, namely that of empirical knowledge. This has no doubt been the view, implicit if not explicit, of many later Kantians.

Even though we need not, therefore, concur with the ultimate, comprehensive verdicts of Kant's opponents, enough has been said, I think, to show that the theological postulates do nonetheless mark a limit to what the Critical system can deliver. There is an unresolved tension between the cognition at which the moral theology aims, and the ultra-thin subjective basis provided for it within Kant's system. The moral theology confronts us with a need of reason which cannot be met - at any rate, not with the same degree of certainty as other parts of the Kantian system enjoy — so long as reason is conceived in Kant's terms, that is, as a formal faculty concerned with the structure and organisation of our representations, lacking any given, intrinsic capacity for objective reference, and without any objective teleological underpinning. (Recall A680/B708: 'Pure reason is in fact concerned with nothing but itself, and can have no other concern'.) ${ }^{44}$

The final point I wish to make concerns the different, progressively oriented reception of the practical postulates by the German Idealists, mentioned at the outset. In several regards, as we have seen, the postulates show the Kantian system straining specifically, towards a closer integration of theoretical and practical reason, and a greater cognitive compass - and seeming to overreach itself, in a way that exposed it to the attacks of Jacobi and others. In this light it is not surprising that the moral theology should have provided — on account of its systematic significance rather than its theistic content - a focal point for the further development of Kantian idealism. ${ }^{45}$

\section{Sebastian Gardner University College London sebastian.gardner@ucl.ac.uk}

\section{Notes}


Abbreviations: Quotations from Kant are taken from the editions listed below. References (e.g., CPrR, 5:119) are to the work, followed by the (volume and) page number of the Akademie Ausgabe, given as marginal pagination in the English translation. Corr: Correspondence, trans. and ed. A. Zweig. Cambridge: Cambridge University Press, 1999.

CPJ: Critique of the Power of Judgement (1790), trans. and ed. P. Guyer, and trans. E. Matthews. Cambridge: Cambridge University Press, 2000.

CPR: Critique of Pure Reason (1781/1787), trans. and ed. P. Guyer and A. W. Wood. Cambridge: Cambridge University Press, 1998.

CPrR: Critique of Practical Reason (1788), in Kant, Practical Philosophy, trans. and ed. M. J. Gregor. Cambridge: Cambridge University Press, 1996.

GMM: Groundwork of the Metaphysics of Morals (1785), in Kant, Practical Philosophy, trans. and ed. M. J. Gregor. Cambridge: Cambridge University Press, 1996.

JL: The Jäsche Logic (1800), in Lectures on Logic, trans. and ed. J. M. Young. Cambridge: Cambridge University Press, 1992.

LM: Lectures on Metaphysics, trans. and ed. K. Ameriks and S. Naragon. Cambridge: Cambridge University Press, 1997.

LR: Lectures on the Philosophical Doctrine of Religion (1783-86), in Kant, Religion and Rational Theology, trans. and ed. A. W. Wood and G. di Giovanni. Cambridge: Cambridge University Press, 1996.

OT: 'What Does it Mean to Orient Oneself in Thinking?' (1786), in Kant, Religion and Rational Theology, trans. and ed. A. W. Wood and G. di Giovanni. Cambridge: Cambridge University Press, 1996.

PM: What Real Progress Has Metaphysics Made in Germany since the Time of Leibniz and Wolff? (1793), trans. P. Heath, in Kant, Theoretical Philosophy After 1781, trans. and ed. H. Allison, G. Hatfield, M. Friedman and P. Heath. Cambridge: Cambridge University Press, 2002.

Proleg: Prolegomena to any Future Metaphysics That Will be Able to Come Forward as Science (1783), trans. G. Hatfield, in Kant, Theoretical Philosophy After 1781, trans. and ed. H. Allison, G. Hatfield, M. Friedman and P. Heath. Cambridge: Cambridge University Press, 2002.

PT: 'Proclamation of the Imminent Conclusion of a Treaty of Perpetual Peace in Philosophy' (1796), trans. P. Heath, in Kant, Theoretical Philosophy After 1781, trans. and ed. H. Allison, G. Hatfield, M. Friedman and P. Heath. Cambridge: Cambridge University Press, 2002.

RWBR: Religion Within the Boundaries of Mere Reason (1793), in Kant, Religion and Rational Theology, trans. and ed. A. W. Wood and G. di Giovanni. Cambridge: Cambridge University Press, 1996.

1 Numerous other passages speaking of practical postulation and cognition, and of 'praktische' or 'moralisch-praktische Realität', may be cited. See, e.g., LM (Metaphysik LI), 28:290-1, CPrR, 5:66 and 5:103, RWBR, 6:5, PM, 20:305-306, and PT, 8:418.

2 The need for clarification concerning the theoretical/practical distinction was felt by Kant's contemporaries: see Friedrich Immanuel Niethammer (1795). Niethammer notes that 'theoretical/practical' can be a distinction (1) of 'Theorie und Praxis, d.i. wie Wissen und Handeln', or (2) of 'zwei verschiedene Arten des Wissens', which in turn divides into (2a) a distinction of 'Wissen selbst' according to its 'Form', viz. 'theoretisches und 
praktisches Wissen', (2b) a distinction of 'Gegenstände', viz. 'Wissen des Theoretischen und des Praktischen'. Niethammer suggests that Critical philosophers have failed to be consistent in their usage (1795: 350).

3 The practical postulates are 'theoretical' (because they express not 'what ought to be' or 'a possible free action', but rather 'what is') but not 'speculative' (because imperatives can be 'derived from them'). See also the distinction of theoretical and practical propositions at JL, 9:110: the former 'relate to the object and determine what belongs or does not belong to it'; the latter 'state the action whereby, as its necessary condition, an object becomes possible'. The hybridity of the practical postulates reflects the fact that the characteristic Euclidean sense of postulate, which no doubt influences Kant, specifies a procedure - e.g. Postulate 1, that one can always draw a straight line between two points - and not (directly) a state of affairs. This suits Kant's purpose in so far as the theological postulates are to be conceived as the correlates of a moral will, but it fosters ambiguity between Kant's postulates as procedures of belief formation ('Let me reason thus...') and as contents believed (' $p$ ').

4 A subtle examination of this issue is provided in Ameriks (2008).

5 Kant distinguishes Glauben, where holding something to be true (Fürwabrhalten) is 'subjectively sufficient' but 'objectively insufficient', from Wissen, where it is 'both subjectively and objectively sufficient' (A822/B850), and says that '[o]nly in a practical relation ... can taking something that is theoretically insufficient to be true be called believing [Glauben]' (A823/B851). He later adds: 'no one will be able to boast that he knows [wisse] that there is a God and a future life [...] the conviction is not logical but moral certainty, since it depends on subjective grounds (of moral disposition)' (A8289/B756-7). The distinction of Glauben and Wissen is restated in JL, 9:66-72.

6 A633/B661. In the Critique of Pure Reason, what Kant later calls 'practical cognition' is called only 'moralische Glaube' (A828/B856).

7 To mention just some of the further places where the problem is compounded: (1) In JL, 9:70, Kant denies that Glauben, including that which is morally necessary, amounts to cognition: 'my belief in the truth of a proposition or the actuality of a thing is what takes the place of a cognition only in relation to me without itself being a cognition [was in Beziehung auf mich nur die Stelle eines Erkenntnisses vertritt, ohne selbst ein Erkenntniß zu sein]'. Elsewhere in the same text, Kant affirms that 'there is a mean [ein Mittleres] between the cognition [Erkenntniß] of an object and the mere presupposition [bloßen Vorraussetzung] of its possibility'; this 'mean' consists in 'accepting' a 'possibility ... as practically necessary' (9:68n). (2) In the late PT, 8:418n, Kant appears to modify his claim: what we postulate is 'not things [Sachen], or in general the existence [Dasein] of any object, but only a maxim (or rule) of the action of a subject'; God and immortality are thus not postulated directly but rather figure as 'conditions' assumed to be present for the performance of the action. With suitable interpolation, strict inconsistency in Kant's texts can perhaps be avoided, but there can be no doubt that at best Kant treads an extremely fine line.

8 Forberg does not in fact present it as an interpretation of Kant's own moral theology and - though he mentions no names — it is no doubt Fichte, whose divine governance essay appears in the very same issue of the Philosophisches Journal, who steers his thinking.

${ }^{9}$ In this spirit, see Neiman 1994, esp. Ch. 4. Neiman puts her view clearly (1994: 147): 'Only by understanding his critique of rationalism and the idea that reason is a matter of 
knowledge can we regard the postulates as rational. In the absence of a general conception of reason, it is natural to view the postulates as instances of failed knowledge and hence, at best, as makeshift replacements for genuinely justifiable statements.'

10 We require 'cause to hope [zu hoffen Ursache]' for merited happiness, A809/B837. In PT, 8:419, Kant distinguishes 'merely the hope of a future life' in which well-being is proportioned to moral worth, from that condition as 'necessarily to be presupposed by reason'. The insufficiency of the 'as if is fully clear from JL, 9:66, where Kant explicitly distinguishes the 'merely problematic' Fürwabrhalten of the case where 'we only act as if we were immortal, from the 'assertoric' case in which 'we believe that we are immortal.

11 As Kant emphasises in many places. See the quotations above from CPrR, 5:133, and CPJ, 5:484-485, and in addition: CPR, A676-678/B703-706, A696-700/B724-728, Proleg, 4:357-358, CPrR, 5:56-57, and PM, 20:279-280, 20:305. In some of these contexts theoretical considerations motivate analogical representation, in others practical. It is worth stressing that the analogicality of our representation of God, though it meets one important objection to the practical cognition of the supersensible, does not itself explain its possibility. I will return to this point later.

12 See, e.g., Kant's letter to Kästner (August 5 [?], 1790) in Corr., 11:186, and PM, passim, esp. 20:300, 20:305-306.

13 This is, in one version, the result that Jacobi seeks to force on Kant: see note 40 below.

14 The dilemma is stated succinctly by Feder: 'If unrestricted obedience to moral laws accords in itself with the nature and highest interest of men, then it necessitates no further presuppositions ... . If, without further presuppositions, it does not accord, then without those presuppositions it is itself ungrounded, and cannot provide the ground of anything' (Feder 1790: 48). Wizenmann 1787: 140 also alleges circularity. Instances of other sorts of criticism concerning the morality/happiness relation include Rehberg 1788, suggesting that Kant's highest good confounds the sensible and intelligible in a way which implies Spinozism; Schleiermacher 1789, arguing that happiness, as a concept reached through 'expansion' from experience of agreeable sensations, cannot pertain to pure reason; Schulze 1795, again alleging that there is no coherent way to mix Kant's moral law with sense-based motivation, and suggesting that the formation of the concept of the highest good must be regarded as merely a ruse of self-love; and Jacobi 1801: 191192, describing the highest good as an incoherent attempt to compensate for the absence of 'Materie' from the Kantian moral law.

15 At A813/B841, Kant describes God and a future world as necessary in order for moral ideas to be 'incentives', Triebfedern - which may seem to make them incentives themselves. See also the earlier LM (Metaphysik $L_{I}$ ), 28:289-291, which shows Kant to be clear that moral conviction, preceding the theological postulates and a condition for assent to them, is the sole 'incentive to virtue', yet at the same time prone to describe the moral law as promising to 'procure' happiness.

16 See Förster 2000, Ch. 5.

17 RWBR, 6:6n: the proposition that God exists 'exceeds the concept of duty that morality contains ... and hence cannot be analytically evolved out of morality'.

18 Pace Schulze, who misconstrues the highest good as a 'Norm unseres Verhaltens' (Schulze 1795: 32), a view echoed in recent literature in Silber's interpretation of the highest good as a rule for guidance playing a determining role in practical judgement. Silber's view is rejected by Beck, Murphy and Auxter. 
19 As Kant's follower Ludwig Heinrich Jakob puts it, the representations of God and immortality are grounds only by way of 'the clearing away of an obstacle' (Jakob 1790: xlix), analogously to the way that the absence of a sandbank allows a ship to sail: the existence of God and immortality are not grounds of cognition of the moral law, nor of its reality; they are connected with it as the 'ground of the possibility of its complete efficacy' (Jakob 1790: xlvii-xlviii).

${ }^{20}$ Fichte, in his early book on revelation, offers a defence of Kant's moral theology which replies effectively to the happiness/morality objection (Fichte 1793, JS2-3). Fichte's argument for the postulates in fact differs from (and extends further than) Kant's, but the key point which his reconstruction of the argument brings to the fore contains the nub of the issue: the theological postulates 'are based merely on the application of the moral law to finite beings ... not on the possibility of the law in itself ... they are ... only for finite natures' (Fichte 1793: 62).

${ }^{21}$ For good measure, Ernst Platner may be added to the list: in his Lehrbuch, a selection from his widely read Aphorismen, Kant's Vernunftglaube is described as a psychological impossibility (1795, §320: 99-100).

22 Wizenmann 1787: 137.

23 Feder 1790: 47-48.

24 'You would need to equip me with a different kind of understanding to the one that I actually have, if you want to make it possible for me to grasp practical interest, considered in isolation, as a valid ground of truth' (Flatt 1789: 19).

25 Schulze 1792: 428.

26 Quoted in Timm 1974: 468-469. I have not been able to locate a copy of Breyer's book, and rely on Timm, and Erdmann 1878: 113.

27 As Schulze notes, the postulate of God's existence 'is based on an inference which reason would not recognise as valid in any other case' (Schulze 1795: 50). See CPrR, 5:143: 'this is the only case in which my interest ... unavoidably determines my judgement'.

28 See also CPJ, 5:468, where Kant explains that the object of the idea of freedom, but not the objects of the other ideas, belongs among the 'facts [Tatsachen]', 'res facti' or 'scibilia' (matters of fact or knowables), of cognition, and CPJ, 5:474: among the three ideas of reason, 'that of freedom is the only concept of the supersensible that proves its objective reality (by means of the causality that is thought in it)'. Again, PT, 8:418: freedom alone has its 'existence [Existenz] ... contained in the categorical imperative'; the other two ideas are brought 'in its wake'.

${ }^{29}$ CPrR, 5:146: 'a voluntary determination of our judgement' which 'has arisen from the moral disposition'. See also CPJ, 4:445-447, 4:458.

30 See also CPrR, 5:143, and JL, 9:69n, 9:70, 9:72.

31 Kant's account of the primacy of practical reason is extremely cautious: theoretical reason 'knows nothing about all that which practical reason offers for its acceptance' but must 'take up [aufnehmen]' and 'assume [annehmen]' practical reason's postulates, 'and try to unite them, as a foreign possession handed over to it, with its own concepts', 'try to compare and connect them with everything that it has within its power', mindful 'that these are not its insights [Einsichten]' (CPrR, 5:120-121). In terms of the interpersonal analogy tacitly employed here, Kant's account is ambiguous between regarding theoretical reason as (i) accepting the testimony of practical reason and committing itself accordingly 
to the truth of the postulates, and (ii) merely declining to dispute practical reason's claim and merely attempting to connect it with its own cognitive stock. Wizenmann claims that Kant's argument amounts only to (ii): 'we presuppose a God merely because it would be stupid not to wish to make use of a concept which is capable of being employed, whether or not the concept corresponds to an object' (1787: 136).

32 Arguably, something of this sort is involved - abductive theoretical reasoning when Kant urges us to reflect that an explanation for God's visibility to pure practical reason and invisibility to theoretical reason would be that God has designed such communication of his existence with a view to preserving the possibility of moral motivation (CPrR, 5:146-147, and LR, 28:1084).

33 Schulze suggests (1792: 436) that the argument structure of the moral proof is extremely close to that of the cosmological argument as Kant presents (and rejects) it in the Transcendental Dialectic: in both cases an inference is drawn from some thing given to us (the world, the moral law), to the reality of the conditions under which alone that thing is thinkable for us (God's existence).

${ }^{34}$ Kant is alert to the distinction: see PT, 8:421, where Kant claims that philosophy in the sense of a 'doctrine of wisdom' is not aware of the distinction between 'what we actually know' of sensible and supersensible objects, and 'what we merely presuppose in a practical respect'. See the interesting comments in Timm 1974: 437-438, regarding the ambiguous relation of Critical philosophy to natural consciousness.

35 The consequent effect of Kant's moral theology, Jacobi alleges, is to undermine the convictions of ordinary understanding by creating an expectation of proof which it fails to fulfil (Jacobi 1811: 368-369).

36 My concentration on critical responses to Kant's moral theology should not be allowed to obscure the fact that it also enjoyed a hugely positive reception in many quarters indeed it was this that drew the critics' fire. Reinhold embraced the moral theology without reservation, finding Kant's theological postulates as unproblematic as they were welcome. The earliest of his influential Letters on Kantian Philosophy in 1786-87 celebrate Kant's epochal achievement in grounding cognition of God (see especially the Second Letter, Reinhold 1786-87/1790: 22-24) — furnishing 'ein Evangelium der reinen Vernunft' - and in his several later treatments of the moral theology Reinhold's accent is firmly on the need to grasp fully (and to make good) the theoretical part of the Critical philosophy on which it depends, rather than elaborating the moral argument itself (see Reinhold 1789, Buch I, and 1786-87/1790: 177-201). Other Kantians either rehearsed the moral argument with minor variations (e.g., Jakob 1790, 1794: 74-94, and 1797) or sought to extend its scope — as in the case of Fichte (1793) and Gottlob Christian Storr's conservative appropriation of Kant's moral theology (Storr 1794). The construal of practical cognition in Reinhold, Jakob, and Storr is straightforwardly realist; nor does Fichte in this early writing give any sign of wishing to reduce religion to morality in the way which would later draw the charge of atheism. Helpful historical studies of the period include Timm 1974, Jaeschke 1990, Ch. 1, and di Giovanni 2005.

37 Schulze also believes, as the earlier parts of his book argue in detail, that the Kantian theory of empirical knowledge demands inferences of this type.

38 Wizenmann 1787: 128-142. Wizenmann focuses his argument specifically on Kant's analogy, in 'What Does it Mean to Orient Oneself in Thinking?', of logical with geographical orientation. 
39 Schleiermacher (1789: 21-25) adds the following twist to the claim that Kant's treatment of human reason undermines the moral argument for God: the concept of the highest good, according to Kant, is generated not by a holy will, but by an imperfect, human will, and since for Kant such a will is defined, like theoretical reason, by the 'Kollision' of ideas of reason with the conditions of sensibility, there can be no justification for regarding its productions as superior to the natural illusions of speculative reason. Kant's extraction of immortality from infinite approximation, Schleiermacher adds, makes the very blunder with which Kant charges dogmatic metaphysics, of mistaking the regulative for the constitutive.

40 And so - Jacobi tells us, drawing an even broader, more sweeping conclusion - must any attempt to philosophise on the basis of mere concepts in abstraction from divine intuitional input (Jacobi 1801: 192). In his extended late reconsideration of the moral theology in light of the development of post-Kantian idealism (Jacobi 1811: 340-378), Jacobi represents the practical postulates as Kant's endeavour to salvage the ideas of God, freedom and immortality in the face of his own principle that we can grasp objects only in so far as we can construct them in thought (Jacobi 1811: 351-352). In more detail, Jacobi's fascinating analysis is that the reality of the objects of the ideas of reason was in fact for Kant wholly axiomatic, an incontrovertible basic conviction. Kant's commitment to Wissenschaft precluded, however, the epistemology which (in light of the impossibility of theoretical proofs of God's existence) this conviction entailed, viz. Jacobi's epistemology of immediate revelations of reason, since to affirm such original cognitions would be to affirm truths without the possibility of proof. Kant was thus forced into the compensatory strategy of elevating practical reason, rendering cognition of the objects of reason mediate, and preserving at least the appearance of proof (Jacobi 1811: 351-364). Had Kant followed to its logical conclusion his principle of the necessity of construction for the conceptual grasping of objects, he would have arrived at the position of Fichte and ultimately that of Schelling - a nihilism which utterly confounds being with the productions of thought. Kant avoided philosophical catastrophe only at the cost of diremption and equivocation; the correct response to his predicament would have been to abandon his commitment to the necessity of wissenschaftlichen Beweis (Jacobi 1811: 365366).

${ }^{41}$ Jakob Hermann Obereit, in his polemical Die verzweifelte Metaphysik (1787), declares that the final upshot of Kantianism is to install in place of a self-subsistent being, viz. God, a 'needy, merely subjectively wheedled presupposition' (Obereit 1787: 16). Breyer, despite his misgivings, did not give up on the moral proof, but rather considered that it showed the need of Critical philosophy to acquire a new foundation, which he anticipated would be supplied in Reinhold's forthcoming Versuch einer neuen Theorie des menschlichen Vorstellungsvermögens. Reading Kant through his moral theology is, it should be noted, not confined to Kant's critics. Kant's follower Daniel Jenisch argues against the 'Hyperkritizismus' and 'unbedingten Idealismus' of certain Kantians (Fichte, presumably), and in support of an interpretation of Kant's transcendental idealism as fundamentally realist in spirit and as ultimately compatible with a dogmatic theology, on the grounds that only the latter can make sense of Kant's moral theology (1796: 194, 402-414).

42 Mention is due here of Maimon, who differs from other figures central to early Kant reception by engaging only minimally with Kant's moral theology. In part this reflects his lack of sympathy with Kant's primacy of the practical - Maimon scorns lovers of 
philosophy who woo the queen of the sciences with their eye on her daughter, morality/theology (Maimon 1794a: 294-296) — but its full explanation lies in Maimon's thesis of the intrinsically fictive and imaginary nature of Kant's ideas of reason, which he develops in a different way from Jacobi and which similarly undercuts at its root the moral argument for God (Maimon 1794a: 200-206, 422-424). In line with his Spinozistic subsumption of practical reason under theoretical reason, the place of Kant's rationally necessary highest good is taken for Maimon by a Trieb towards complete perfection (Maimon 1794a: 201, 424), determined more exactly as 'striving for knowledge of the truth' (Maimon 1794a: 226, 1794b: 407-408). From such a distance, Kant's moral theology does not present a salient, worthwhile point of engagement.

43 See note 11 above, regarding analogical representation.

44 The following is not an issue that I can pursue here, but it should be noted that even at this point the story does not stop and the case against Kant is not closed, since the severity of the problem which in fact results for the moral theology depends, it may reasonably be argued, on what it is being asked to do: if it is required not that it refute the sceptic, but merely that it furnish a warrant sufficient for apologetic purposes, against a backdrop of established theistic belief, then arguably it earns its place in the Critical system. A strictly apologetic reading of the theological postulates is defended by Jakob (1797: xvi-xvii).

$45 \mathrm{I}$ am grateful for comments made by the audience at the Hegel Society conference in Oxford, September 2010, at which this paper was presented, and to the UK Arts and Humanities Research Council, which funded the research leave that provided the opportunity to compose an earlier draft. I should also acknowledge that, for reasons of space, I have in general not given references to or engaged with the contemporary secondary literature on Kant's moral theology which has informed my discussion in this paper.

\section{Bibliography}

Ameriks, K. (2008), 'The End of Kant's Critiques: Kant's Moral "Creationism”, in P. Muchnik (ed.), Rethinking Kant. Newcastle: Cambridge Scholars.

Erdmann, B. (1878), Kant's Criticismus in der ersten und in der zweiten Auflage der Kritik der reinen Vernunft. Ein historische Untersuchung. Leipzig: Voss.

Feder, J. G. (1790), 'Ueber die Kantische Moraltheologie', Philosophische Bibliothek, Bd. 3, 13-66.

Fichte, J. G. (1793), Attempt at a Critique of All Revelation, trans. G. Green. New York: Cambridge University Press, 1978.

Flatt, J. F. (1789), Briefe über den moralischen Erkenntnisgrund der Religion überhaupt, und besonders in Beziehung auf die Kantische Philosophie. Tübingen: Cotta.

Forberg, F. K. (1798), 'Entwickelung des Begriffs der Religion', Philosophisches Journal, Bd. 8, Heft 1, 21-46. [Reprinted in: H. Lindau (ed.), Die Schriften zu J. G. Fichtes Atheismus-Streit. München: Georg Müller, 1912, pp. 37-58.] 
Förster, E. (2000), Kant's Final Synthesis. An Essay on the Opus Postumum. Cambridge, Mass.: Harvard University Press.

di Giovanni, G. (2005), Freedom and Religion in Kant and His Immediate Successors: The Vocation of Humankind, 1774-1800. Cambridge: Cambridge University Press.

Jacobi, F. H. (1787), David Hume on Faith, or Idealism and Realism. A Dialogue, in The Main Philosophical Writings and the Novel "Allwill," trans. and ed. G. di Giovanni, pp. 253-338. Montreal \& Kingston: McGill-Queen's University Press.

Jacobi, F. H. (1801), Ueber das Unternehmen des Kriticismus die Vernunft zu Verstande zu bringen, in Werke, Bd. 3, pp. 57-195. Leipzig: Gerhard Fleischer, 1812-25. [Reproduced, Darmstadt: Wissenschaftliche Buchgesellschaft, 1968.]

Jacobi, J. F. (1811), Von den göttlichen Dingen und ibrer Offenbarung, in Werke, Bd. 3, pp. 245460. Leipzig: Gerhard Fleischer, 1812-25. [Reproduced, Darmstadt: Wissenschaftliche Buchgesellschaft, 1968.]

Jaeschke, W. (1990), Reason in Religion: The Foundations of Hegel's Philosophy of Religion, trans. J. M. Stewart and P. C. Hodgson. Berkeley: University of California Press.

Jakob, L. H. (1790), Beweis für die Unsterblichkeit der Seele aus dem Begriffe der Pflicht. Eine Preißschrift mit einiger Veränderung von dem Verfasser selbst aus dem Lateinischen übersezt. Halle: Züllichau.

Jakob, L. H. (1794), Philosophische Sittenlehre. Halle: Hemmerde und Schwetschke. [Reproduced, Bruxelles: Culture et civilisation, 1969.]

Jakob, L. H. (1797) Die Allgemeine Religion. Ein Buch für gebildete Leser. Halle: Hemmerde und Schwetschke.

Jenisch, D. (1796), Über Grund und Werth der Entdeckungen des Herrn Professor Kant in der Metaphysik, Moral and Aesthetik. Ein Acceßit der Königl. Preuß. Akademie. Berlin: Vieweg. [Reproduced, Bruxelles: Culture et civilisation, 1973.]

Maimon, S. (1794a), Versuch einer neuen Logik oder Theorie des Denkens, nebst angehängten Briefen des Philateles an Aenesidemus. Berlin: Felisch.

Maimon, S. (1794b), 'Versuch einer neuen Darstellung des Moralprinzips und Dedukzion seiner Realität', in Berlinische Monatsschrift, Bd. 24, 402-453.

Niethammer, F. I. (1795), 'Einige Bemerkungen über den Gebrauch der Ausdrücke theoretisch und praktisch, und Theorie und Praxis', in Philosophisches Journal einer Gesellschaft Teutscher Gelehrten, Bd. 3, H. 4, 321-351. [Reproduced, Hildesheim: Georg Olms, 1969.]

Obereit, J. H. (1787), Die verzweifelte Metaphysik zwischen Kant und Wizenmann. Berlin(?). Platner, E. (1795), Lehrbuch der Logik und Metaphysik. Leipzig: Schwickertschen Verlage.

Rehberg, A. W. (1788), 'Rezension der Kritik der praktischen Vernunft', Allgemeine Literatur Zeitung 188 (August 6, 1788), 345-352. [Reprinted in R. Bittner and K. Cranmer (eds.), Materialien zu Kants Kritik der praktischen Vernunft, pp. 179-196. Frankfurt: Suhrkamp, 1975.] 
Reinhold, K. L. (1786-87/1790), Letters on Kantian Philosophy, trans. J. Hebbeler, ed. K. Ameriks. Cambridge: Cambridge University Press, 2005.

Reinhold, K. L. (1789), Versuch einer neuen Theorie des menschlichen Vorstellungsvermögens. Prag und Jena: Widtmann und Mauke.

Schleiermacher, F. D. E. (1789), On the Highest Good, trans. H. V. Froese. Lewiston, NY: Edwin Mellen Press, 1992.

Schulze, G. E. (1792), Aenesidemus oder über die Fundamente der von dem Herrn Prof. Reinhold in Jena gelieferten Elementar-Philosophie, nebst einer Verteidigung gegen die Anmassungen der Vernunftkritik. Helmstädt.

Schulze, G. E. (1795), Einige Bemerkungen über Kants philosophische Religionslehre. Kiel: Bohn. Storr, G. C. (1794), Bemerkungen über Kants philosophische Religionslebre. Tübingen: Cotta.

Timm, H. (1974), Gott und die Freibeit. Studien zur Religionsphilosophie der Goethezeit, Bd. 1. Die Spinozarenaissance. Frankfurt a. M.: Klostermann.

Vaihinger, H. ([1911] 1949), The Philosopby of 'As If'. A System of the Theoretical, Practical and Religious Fictions of Mankind, trans. C. K. Ogden. London: Routledge \& Kegan Paul.

Wizenmann, T. (1787), 'An den Herrn Professor Kant, von dem Verfasser der Resultate Jacobi'scher und Mendelssohn'scher Philosophie', Deutsches Museum, 2e. Stück, Februar 1787, pp. 116-156. 